\title{
Efficacy of arbidol on lethal hantaan virus infections in suckling mice and in vitro
}

\author{
Hai-ying DENG ${ }^{1,2}$, Fan $\mathrm{LUO}^{1}$, Li-qiao SHI ${ }^{1}$, Qiong ZHONG ${ }^{1}$, Ying-juan LIU ${ }^{1}$, Zhan-qiu YANG ${ }^{1, *}$ \\ ${ }^{1}$ State Key Laboratory of Virology, Institute of Medical Virology, School of Medicine, Wuhan University, Wuhan 430071, China; ${ }^{2}$ Medical \\ School of Wuhan University of Science and Technology, Wuhan 430065, China
}

\begin{abstract}
Aim: Arbidol is an immunomodulator that was first developed in Russia. In this study, we report the antiviral activity of arbidol against Hantaan virus (HTNV) in vitro and in vivo.

Methods: The antiviral activity of arbidol in vitro was determined by plaque-forming assay, ranging from 0.5 to $8 \mu \mathrm{g} / \mathrm{mL}$. To investigate whether arbidol has an antiviral effect in vivo, suckling BALB/c mice infected with HTNV were treated with arbidol at $24 \mathrm{~h}$ before infection with a 5,10 or $20 \mathrm{mg} \cdot \mathrm{kg}^{-1} \cdot \mathrm{d}^{-1}$, once per day, for 10 days. On day 12 and 28 post infection (pi), histopathological changes and viral antigen were detected. On days $4,8,12$, and 16 pi, the viral load of target organs and serum TNF- $\alpha$ levels of arbidol-treated animals were determined.

Results: Arbidol was found to have potent inhibitory activity against HTNV when added in vitro before or after viral infection, with a $50 \%$ inhibitory concentration $\left(\mathrm{IC}_{50}\right)$ of 0.9 and $1.2 \mathrm{\mu g} / \mathrm{mL}$, respectively. The $50 \%$ lethal dose $\left(\mathrm{LD}_{50}\right)$ of arbidol for suckling mice was 78.42 $\mathrm{mg} \cdot \mathrm{kg}^{-1} \cdot \mathrm{d}^{-1}$. Oral administration of arbidol increased both survival rate and mean time to death (MTD). Treatment with arbidol reduced histopathological changes, decreased viral load and viral antigen levels, and modulated the level of serum TNF- $\alpha$.

Conclusion: Arbidol has the ability to elicit protective antiviral activity against HTNV in vivo and in vitro.
\end{abstract}

Keywords: antiviral activity; arbidol; Hantaan virus; suckling mice; in vitro; in vivo

Acta Pharmacologica Sinica (2009) 30: 1015-1024; doi: 10.1038/aps.2009.53; published online 8 June 2009

\section{Introduction}

Hantaviruses are enveloped viruses of the genus Hantavirus, family Bunyaviridae, with a genome consisting of three segments of negative-sense RNA. The large (L), small (S), and medium $(\mathrm{M})$ segments encode RNA-dependent RNA polymerase, the nucleocapsid $(\mathrm{N})$ protein, and two envelope glycoproteins (G1 and G2), respectively ${ }^{[1]}$. Hantaviruses are transmitted to humans via inhalation of aerosolized excreta from infected rodents. The infection can lead to hantavirus pulmonary syndrome (HPS) and hemorrhagic fever with renal syndrome (HFRS) ${ }^{[1,2]}$. More than 10000 cases of HFRS are reported annually worldwide, mostly in Asia and Europe ${ }^{[3,4]}$. Lethality ranges from $1 \%$ for Puumala virus (PUUV) and Seoul virus infections to approximately $15 \%$ for Hantaan (HTNV) virus infections ${ }^{[5-8]}$.

Vaccination is the preferred method for controlling HFRS and reducing the impact of incidence. Several inactivated HTNV and Seoul virus vaccines for HFRS have been used ${ }^{[8]}$,

\footnotetext{
* To whom correspondence should be addressed.

E-mail zqyang@whu.edu.cn

Received 2009-02-20 Accepted 2009-03-31
}

but they are not yet completely effective or protective against all strains. Additionally, not all people at risk can receive the vaccination, especially those in regions having only sporadic outbreaks.

During the past few years, extensive efforts have been made in the search for effective anti-HTNV agents. Some nucleoside analogs have been found to be highly inhibitory in animal models ${ }^{[9]}$, but ribavirin is the only antiviral agent known to be successful against HTNV infections in clinical trails ${ }^{[10]}$. However, the utilization of ribavirin is limited by its myelosuppression and toxicity ${ }^{[1-13]}$. No antiviral agent has been approved by the Food and Drug Administration (FDA) to treat HFRS ${ }^{[5]}$. Therefore, an effort to seek alternative agents is strongly desirable.

Arbidol (ARB; $1 H$-indole-3-carboxylic acid, 6-bromo-4[(dimethylamino)-methyl]-5-hydroxy-1-methyl-2-[(phenylthio) methyl]-, ethylester, monohydrochloride) is an immunomodulator that was developed in Russia ${ }^{[14]}$. It has been shown to have broad antiviral effects against viruses such as influenza virus, coxsackievirus, respiratory syncytial virus ${ }^{[15]}$, and hepatitis $\mathrm{C}$ virus $(\mathrm{HCV})^{16]}$. The antiviral mechanisms of arbidol may be due to increased interferon production or 
inhibition of enveloped virus fusion within endosomes ${ }^{[17]}$. The aim of the present study was to evaluate the anti-HTNV activity of arbidol in vivo and in vitro.

\section{Materials and methods \\ Virus}

The 76-118 strain of Hantaan virus was obtained from the Institute of Virology, Chinese Academy of Preventive Medicine, Beijing, China. The virus was propagated five times in Vero E6 cells (ATCC CRL 1586) to achieve a titer of $1 \times 10^{6}$ $\mathrm{TCID}_{50} / 0.1 \mathrm{~mL}$. For animal inoculation, viral stock was diluted in minimal essential medium (MEM) (containing 2\% FCS, $100 \mathrm{U} / \mathrm{mL}$ penicillin, and $0.1 \mathrm{mg} / \mathrm{mL}$ streptomycin) and stored in multiple single-use aliquots at $-80^{\circ} \mathrm{C}$.

\section{Reagents and compounds}

Arbidol (obtained from Qianjiang Pharmaceutical Co, LTD, Hubei, China) was initially dissolved in dimethyl sulfoxide (DMSO) and then further diluted with MEM containing 2\% FCS (2\% MEM) for testing in vitro. The final maximum DMSO concentration was $0.05 \%$, and an equivalent amount of DMSO was added to all no-drug control samples. Arbidol was suspended in $0.5 \%$ sterilized methylcellulose for testing in vivo. A monoclonal antibody that targets nucleocapsid protein $\left(\mathrm{A}_{35}\right.$, provided by the Institute of Virology, Chinese Academy of Preventive Medicine, Beijing, China) was used as the primary antibody for indirect immunofluorescence at a $5 \mu \mathrm{g} / \mathrm{mL}$ concentration. The second antibody was a fluorescein isothiocyanate (FITC)-conjugated goat anti-mouse IgG antibody (R\&D Systems, Minneapolis, MN).

\section{In vitro evaluation of arbidol}

\section{Cell viability assay}

To determine the cytotoxic concentration of arbidol, monolayers of confluent Vero E6 cells were exposed to various concentrations of arbidol in 2\% MEM, and the dilution medium with $0.05 \%$ DMSO was used as the control. After 10 days of incubation, cell viability was examined by the MTT colorimetric assay ${ }^{[18]}$. The median cytotoxic concentration $\left(\mathrm{CC}_{50}\right)$ was the concentration $(\mu \mathrm{g} / \mathrm{mL})$ required to reduce cell viability by $50 \%$.

\section{Viral yield reduction assay}

Confluent Vero E6 cells were infected with 100 TCID $_{50} / 0.1$ $\mathrm{mL}$ of HTNV. After $2 \mathrm{~h}$ of adsorption at $35^{\circ} \mathrm{C}$, the cells were covered with $2 \%$ MEM containing varying concentrations of arbidol. At 10 days pi, cultures were subjected to two cycles of freezing and thawing, followed by centrifugation at low speed $(1000 \times g)$, and the supernatants were titered by plaque assay $^{[19,20]}$. In brief, supernatants of serial 10-fold dilutions were inoculated onto Vero E6 cell monolayers in 24-well plates and then overlaid with agarose overlay medium. After incubation for 5 days at $35^{\circ} \mathrm{C}$, a second layer of agarose including neutral red $(0.167 \mathrm{mg} / \mathrm{mL})$ was added to the well and incubated for an additional 2 days at $35{ }^{\circ} \mathrm{C}$ in $5 \% \mathrm{CO}_{2}$ atmosphere. After incubation, the number of plaques was counted. Antivi- ral activity was defined as $50 \%$ inhibitory concentration $\left(\mathrm{IC}_{50}\right)$, $i e$, the concentration required to reduce viral yield by $50 \%$ compared with the untreated control cultures. Thus, the selective index (SI) for arbidol was determined from $\mathrm{CC}_{50} / \mathrm{IC}_{50}$.

\section{Pre-treatment assay}

To evaluate the effects of arbidol on prophylaxis for cell infection, serial two-fold dilutions of arbidol were dissolved in $2 \%$ MEM and incubated with cells for $24 \mathrm{~h}$ at $35{ }^{\circ} \mathrm{C}$ in $5 \% \mathrm{CO}_{2}$ atmosphere. After removal of the compound, the cells were washed twice with phosphate buffered saline (PBS) and the cell monolayers were infected with $100 \mathrm{TCID}_{50} / 0.1 \mathrm{~mL}$ of HTNV. The cell monolayers were grown in 2\% MEM (including $0.05 \%$ DMSO) and samples grown in $0.05 \%$ DMSO without arbidol were used as the control. Ten days after inoculation, cultures were frozen and viral yields were determined by plaque assay. The $\mathrm{IC}_{50}$ s were determined as described above.

\section{Direct virucidal assay}

Viral suspensions containing $100 \mathrm{TCID}_{50} / 0.1 \mathrm{~mL}$ of viral stock were incubated with an equal volume of medium with or without serial two-fold dilutions of arbidol for $2 \mathrm{~h}$ at $35^{\circ} \mathrm{C}$. Duplicate cultures of confluent Vero E6 cells were infected with $200 \mu \mathrm{L}$ mixed suspension. The inoculate was removed at $2 \mathrm{~h}$ post-infection and maintained with medium containing $2 \%$ FCS at $35{ }^{\circ} \mathrm{C}$ for 10 days. The viral yield of the collected fractions was determined by plaque assay.

\section{Antiviral activity in vivo}

\section{Animals}

Specific-pathogen-free pregnant BALB/c mice were obtained from the Animal Research Center of Wuhan University. Animals were assigned to individual cages and given food and water. They were observed daily, and births were timed to the nearest day. Based on the $50 \%$ lethal dose $\left(\mathrm{LD}_{50}\right)$ of HTNV intracranial (ic) inoculation in suckling mice, 1- to 2-day-old mice were intracranially inoculated with $100 \mathrm{LD}_{50}$ of viral stock to determine an acceptable infection dose. All work with these animals was performed in the Animal Biosafety Level 3 (ABSL-3) Laboratory of the Animal Research Center at Wuhan University and was approved by the Institutional Animal Care and Use Committee.

\section{In vivo toxicity determinations}

Arbidol was evaluated for the dose considered lethally toxic in 1-day-old mice. The doses studied were 160, 80, 40, 20 and $10 \mathrm{mg} \cdot \mathrm{kg}^{-1} \cdot \mathrm{d}^{-1}$. Normal controls received $0.5 \%$ methylcellulose solution instead of arbidol. Mice $(n \geq 9)$ were treated by oral gavage once a day for 10 days. Animal weights were determined every day. They were observed for death daily for a total of 20 days.

\section{Experimental design for animal studies}

Suckling mice (2 days old) were inoculated ic with $100 \mathrm{LD}_{50}$ of viral stock. The mice were randomly divided into five groups (35 mice per group) and arbidol was tested with the follow- 
ing dosage regimens: 5,10 , or $20 \mathrm{mg} \cdot \mathrm{kg}^{-1} \cdot \mathrm{d}^{-1}$ once a day for 10 days. Treatment was initiated at $24 \mathrm{~h}$ before infection, by the same investigator, and with the dose corrected for weight change. Placebo controls (inoculated with 100 LD $_{50}$ of HTNV) and normal controls (inoculated with 2\% MEM) received 0.5\% methylcellulose solution instead of arbidol. Animals were observed twice daily and weighed once daily. Mice were observed daily for mortality for 28 days after infection. Death occurring $24 \mathrm{~h}$ after viral inoculation was considered traumatic, and such animals were considered withdrawals. The effect of arbidol was estimated using the reduction in the rate of mortality and prolongation of mean time to death (MTD). Four mice were sacrificed for each experimental point (days $4,8,12$, and 16 pi), and survivors were euthanized on day 28 pi. Sera were pooled for all studies. Brains, lungs, and kidneys were aseptically dissected from the animals and divided into three parts: one-third was frozen for antigen detection by indirect immunofluorescence (IFA), one-third was placed in formalin for histological examination, and the rest was stored at $-80^{\circ} \mathrm{C}$ for virological parameter determination.

\section{Histological study}

Four animals were sacrificed on day $12 \mathrm{pi}$, and the survivors were euthanized on day 28 pi. Brain, lung, and kidney slices were fixed in $10 \%$ formalin, dehydrated in ethanol, and embedded in paraffin. Sections of $5 \mu \mathrm{m}$ thickness were stained with hematoxylin and eosin (H\&E).

\section{IFA}

On day 12 pi, four animals were sacrificed, and the survivors were euthanized on day 28 pi. Frozen sections of brain, lung, and kidney were prepared in a cryostat. IFA was carried out as reported previously ${ }^{[20]}$ with the N-specific monoclonal antibody $\mathrm{A}_{35}$. Specific reactions between $\mathrm{A}_{35}$ and $\mathrm{N}$ protein were detected with FITC-conjugated goat anti-mouse IgG and observed with fluorescent microscopy (Olympus CX-41, Japan).

\section{$R T-P C R$}

On days 4, 8, 12, and 16 pi, total RNA was isolated from the lungs, brains, and kidneys of HTNV-infected mice using TRIzol® Reagent (Invitrogen, Carlsbad, CA), according to the manufacturer's instructions. RNA $(1.0 \mu \mathrm{g})$ was reverse transcribed in a reaction volume of $20 \mu \mathrm{L}$. Synthesis of cDNA was carried out at $42^{\circ} \mathrm{C}$ for $60 \mathrm{~min}$, followed by a denaturation step at $95^{\circ} \mathrm{C}$ for $5 \mathrm{~min}$. The reverse transcription products served as templates for PCR. The PCR protocol consisted of 30 cycles of denaturation $\left(94^{\circ} \mathrm{C}\right.$ for $\left.1 \mathrm{~min}\right)$, annealing $\left(55^{\circ} \mathrm{C}\right.$ for $2 \mathrm{~min})$, and extension $\left(72^{\circ} \mathrm{C}\right.$ for $\left.3 \mathrm{~min}\right)$, using a Thermal Cycler (Eppendorf, German). The $S$ segment of the viral genome was chosen for detection and the primer sequences used were 5'-TGA GAA ATG TGT ATG ACA TGA-3' (sense) and 5'-ACT AGA CAC TGT TTC AAA TGA-3' (antisense). The parallel expression of $\beta$-actin mRNA was tested under the same PCR conditions as an internal standard, using the primers $5^{\prime}$-TCA TCA CTA TTG GCA ACG AGC-3' (sense) and 5'-AAC AGT
CCG CCT AGA AGC AC-3' (antisense). For quantification, standard curves were generated to show that PCR detection was in the linear range. PCR bands on the gel were scanned using a computer analysis system (Bandscan 5.0, Glyko), and the viral mRNA signal was normalized relative to the corresponding $\beta$-actin mRNA signal from the same sample. Data are presented as the mRNA/ $\beta$-actin ratio.

\section{Lung, kidney and brain viral titers determination}

At days 4, 8, 12, and 16 pi, the organs of four mice from each group were homogenized to $10 \%$ (weight/volume) suspensions in test medium. The homogenates were subjected to two cycles of freezing and thawing followed by centrifugation at low speed $(1000 \times g)$. The titers of infectious viral particles were determined by the standard plaque formation assay.

\section{Detection of TNF- $\alpha$ in serum by enzyme-linked immunosorbent assay (ELISA)}

Blood was obtained at days 4, 8, 12, and 16 pi and the serum stored at $-80{ }^{\circ} \mathrm{C}$. TNF-a was detected in the serum by QuantiKine quantitative sandwich enzyme immunoassay (EIA) (R\&D Systems, Minneapolis, MN) according to the manufacturer's instructions.

\section{Statistical analysis}

The data were analyzed using SPSS 16.0 software. One-way ANOVA was used to determine statistical differences for MTD, serum TNF-a level, and mRNA/ $\beta$-actin ratios. A log rank test was used to evaluate the survival distributions for the different levels of group. Any $P$ value less than 0.05 was considered to indicate statistical significance.

\section{Results}

\section{Inhibition of HTNV in vitro}

Vero E6 cells were treated with arbidol concentrations in the range of 1 to $20 \mu \mathrm{g} / \mathrm{mL}$ and cell viability was investigated by MTT assay. Arbidol did not significantly affect the viability of cells at concentrations lower than $8 \mu \mathrm{g} / \mathrm{mL}$ and the $\mathrm{CC}_{50}$ of arbidol was $15.64 \mu \mathrm{g} / \mathrm{mL}$. We therefore examined the antiHTNV activity of arbidol at concentrations of $8 \mu \mathrm{g} / \mathrm{mL}$ or lower. The results are summarized in Table 1. Overall, arbidol was efficacious against HTNV when added before or after viral infection, with mean $\mathrm{IC}_{50}$ values determined by use of

Table 1. Antiviral activity of arbidol against HTNV in vitro. Values are shown from three independent experiments. Mean \pm SD.

\begin{tabular}{lcc}
\hline & $\mathrm{IC}_{50}(\mu \mathrm{g} / \mathrm{mL})$ & $\begin{array}{c}\text { Selectivity } \\
\text { index (SI) }\end{array}$ \\
\hline Drug added before infection & $0.9 \pm 0.2$ & 17.4 \\
Drug added after infection & $1.2 \pm 0.3$ & 13.0 \\
Virucidal assay & $\mathrm{ND}$ & $\mathrm{ND}$ \\
\hline
\end{tabular}

ND: Not determined. $\mathrm{IC}_{50}$ is the inhibitory concentration required to reduce viral replication by $50 \%$, determined by probit analysis with SPSS 16.0 software. $\mathrm{SI}=\mathrm{CC}_{50} / \mathrm{IC}{ }_{50}$ 
plaque-forming assay. No directly virucidal effects of arbidol were found at concentrations lower than $8 \mu \mathrm{g} / \mathrm{mL}$ in this experiment.

\section{Efficacy of arbidol on lethal HTNV infections in suckling mice The $L D_{50}$ of arbidol}

Oral gavage treatment with arbidol for 10 days indicated that the $\mathrm{LD}_{50}$ of arbidol was $78.42 \mathrm{mg} \cdot \mathrm{kg}^{-1} \cdot \mathrm{d}^{-1}$. It should be noted that no obvious weight loss was seen at dosages below 40 $\mathrm{mg} \cdot \mathrm{kg}^{-1} \cdot \mathrm{d}^{-1}$. No attempt was made to determine the cause of death for the mice in this range-finding study.

\section{Protective efficacy of arbidol in suckling mice}

Suckling mice were infected with HTNV as described above and treated with the following dosage regimens: 5,10 , or 20 $\mathrm{mg} \mathrm{kg}^{-1} \cdot \mathrm{d}^{-1}$ once a day for 10 days. Animals were observed and weighed individually every day. The clinical symptoms evaluated in these animals included transient state of hyperactivity, weight loss, and ruffled appearance of their coats accompanied by hunched posture and progressively diminishing mobility. Paralysis of both hind limbs appeared prior to death. Compared with the placebo-treated animals, arbidoltreated animals died later and appearance of clinical signs was reduced in a dose-dependent manner. Weight recovered and symptoms disappeared by day 28 in the survivors (Figure 1). All placebo-treated mice died, with an MTD of 17.17 days whereas treatment with arbidol increased both survival rate and MTD (Figure 1). Arbidol at $10 \mathrm{mg} \cdot \mathrm{kg}^{-1} \cdot \mathrm{d}^{-1}$ increased the survival rate to $33.3 \%$ and MTD to 21.5 days $(P<0.05)$ and at 20 $\mathrm{mg} \mathrm{kg}^{-1} \cdot \mathrm{d}^{-1}$ increased the survival rate to $60 \%$ and MTD to 23.8 days $(P<0.05)$.

\section{Effect of arbidol on histopathological changes}

Four animals from each group were sacrificed on day 12 pi, and the survivors were sacrificed on day 28 pi. The lungs, brains, and kidneys were collected for pathological examination. The organs of normal controls did not exhibit any modification in their structure (see Figure 2D). However, all infected animals developed histopathological changes with various degree of severity on day $12 \mathrm{pi}$. The lesions were as follows (Figure 2A): brain (scattered hemorrhages, congestion, edema, and focal necrosis), lung (thickened alveolar walls, interstitial lymphocyte and macrophage infiltration, and hemorrhage), and kidney (focal renal interstitial hemorrhage, congestion). On day $12 \mathrm{pi}$, the lungs of arbidol-treated animals (10 and $20 \mathrm{mg} \cdot \mathrm{kg}^{-1} \cdot \mathrm{d}^{-1}$ ) demonstrated a significant reduction in histopathological changes, and the brains and kidneys showed decreased edema and focal hemorrhage compared to placebo controls (Figure 2B). On day 28 pi, no histological changes were detected in the lungs, kidneys and brains of survivors (Figure 2C).

\section{Inhibition of viral antigen expressed in the organs by arbidol}

We detected viral antigen in the lungs, brains, and kidneys of animals using IFA as described above. The organs of normal controls did not exhibit immunofluorescence (Figure 3D). In
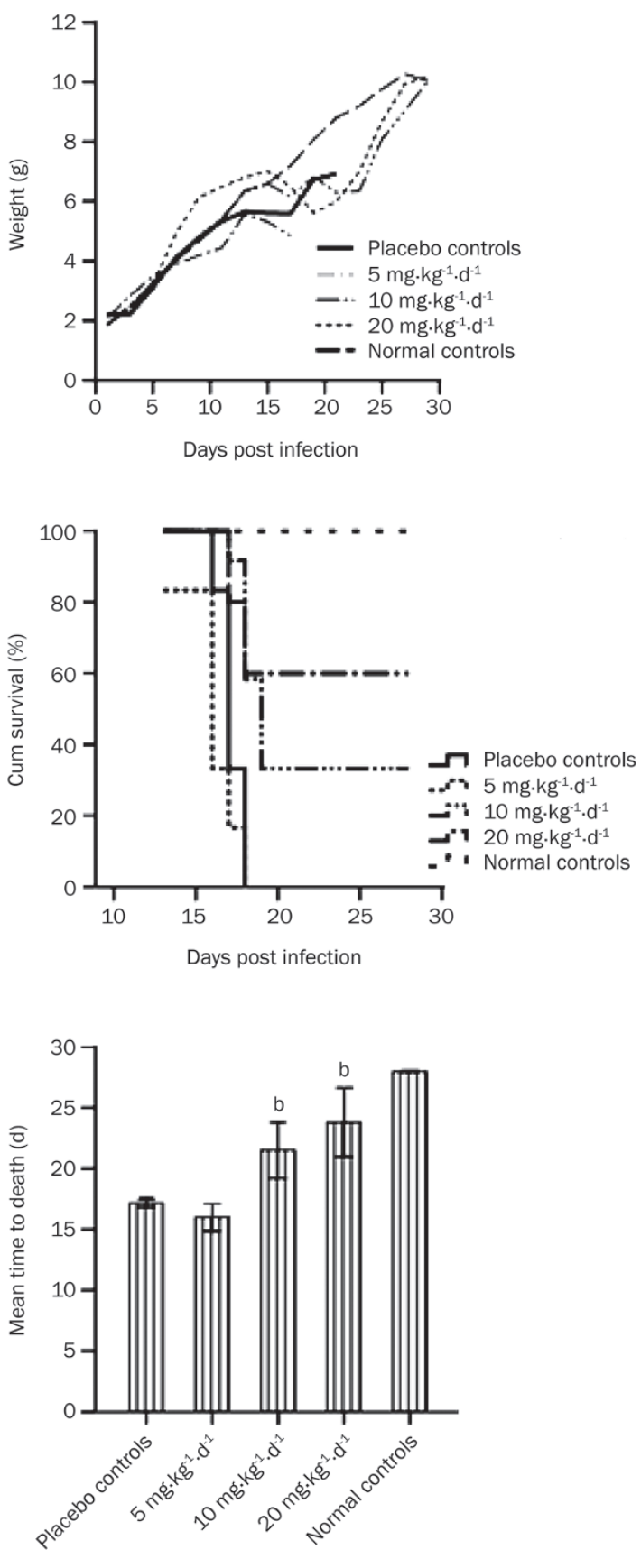

Group

Figure 1. Effects of orally administered arbidol on the lethal HTNV challenge model. Arbidol at 5,10 , and $20 \mathrm{mg} \cdot \mathrm{kg}^{-1} \cdot \mathrm{d}^{-1}$ was orally administered $24 \mathrm{~h}$ before infection with $100 \mathrm{LD}_{50}$ of HTNV (76-118 strain). Mice were weighed individually every day. The survival rates of HTNV infected mice were calculated daily, and the experiment was terminated on day 28 . Statistical analysis using the log rank test determined the increase in survival rate with arbidol treatment to be significant $(P<0.05)$. One-way ANOVA was used to determine statistical differences for MTD. ${ }^{\mathrm{b}} P<0.05$ vs placebo-treated controls.

comparison, specific fluorescence was observed in the lungs, brains, and kidneys of placebo controls (Figure 3A). At day 12 $\mathrm{pi}$, the lungs of arbidol-treated animals $\left(10\right.$ and $\left.20 \mathrm{mg} \cdot \mathrm{kg}^{-1} \cdot \mathrm{d}^{-1}\right)$ 


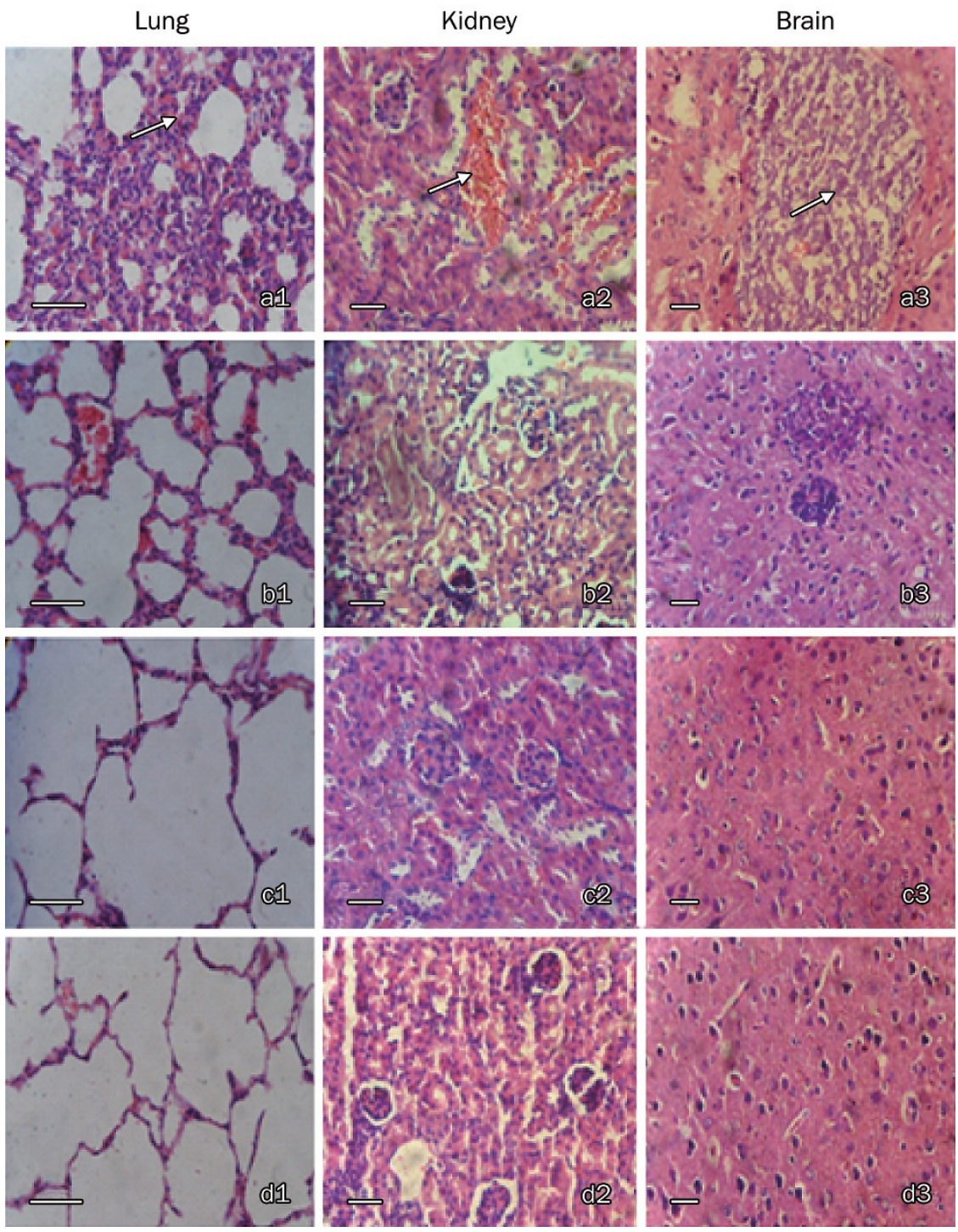

Figure 2. Effects of arbidol on organ histopathology in suckling mice infected with HTNV $(\times 400)$. On day $12 \mathrm{pi}$ and 28 pi four mice were sacrificed to prepare sections for H\&E stain. (a1-a3) Histological section from a placebo controls animal (arrow in upper panel). (a1) Lung (thickened alveolar walls, interstitial lymphocyte and macrophage infiltration, and hemorrhage). (a2) Kidney (focal renal interstitial hemorrhage, congestion). (a3). Brain (focal necrosis and hemorrhage). (b1-b3) Histological section from one of the mice treated with arbidol at $20 \mathrm{mg} \cdot \mathrm{kg}^{-1} \cdot \mathrm{d}^{-1}$ on day 12 pi. (c1-c3) Histological section from one of the mice treated with arbidol at $20 \mathrm{mg} \cdot \mathrm{kg}^{-1} \cdot \mathrm{d}^{-1}$ on day 28 pi. (d1-d3) Histological section from a normal control. Scale bar $=25 \mu \mathrm{m}$. demonstrated a significant reduction in immunofluorescence, and a reduction in viral antigen was expressed in the brains and kidneys compared to placebo-treated controls (Figure 3B). On day 28 pi, viral antigen was not detected in the brains of survivors (Figure 3C). Lungs and kidneys showed much less immunofluorescence (Figure 3C).

\section{Inhibition of HTNV mRNA by arbidol}

Semi-quantitative RT-PCR analysis was performed on total RNA extracted from tissues of infected animals as described above in "Materials and Methods." No viral mRNA was detected on day 4 pi in the lungs, kidneys, and brains of mice infected by HTNV (Figure $4 \mathrm{~A}$ ). The mRNA/ $\beta$-actin ratio in the lungs decreased in a dose- and time-dependent manner. On day 16 pi, no viral mRNA was detected in the lungs of animals treated with arbidol at 10 or $20 \mathrm{mg} \cdot \mathrm{kg}^{-1} \cdot \mathrm{d}^{-1}$, and the ratio in the brains decreased in a dose-dependent manner. Animals treated with arbidol at $20 \mathrm{mg} \cdot \mathrm{kg}^{-1} \cdot \mathrm{d}^{-1}$ showed an mRNA/ $\beta$-actin ratio in the kidneys of $0.24(P<0.05)$, whereas the ratio of placebo controls was 0.88 (Figure 4B). To further investigate the effect of arbidol on HTNV gene expression, the viral mRNA in the tissues of survivors (day 28 pi) was measured. After treatment with arbidol at 10 or $20 \mathrm{mg} \cdot \mathrm{kg}^{-1} \cdot \mathrm{d}^{-1}$, no viral mRNA was detected in the lungs or brains, but viral mRNA was detected in the kidneys.

\section{Reduction of HTNV titers by arbidol}

The titers of infectious viral particles were determined by the standard plaque formation assay described above. No infectious viral particles were detected on day 4 pi in the tissues of animals infected by HTNV. As shown in Figure 4C, viral titers in the lungs of animals treated with arbidol were reduced in a dose- and time-dependent manner in comparison to placebotreated controls. After treatment with arbidol at $20 \mathrm{mg} \cdot \mathrm{kg}^{-}$ ${ }^{1} \cdot \mathrm{d}^{-1}$, viral titers in the kidneys showed a significant reduction at day 16 pi. The mean viral yields of the brains decreased in a dose-dependent manner at day 16 pi. No infectious viral particles were detected in the lungs, kidneys, and brains of 

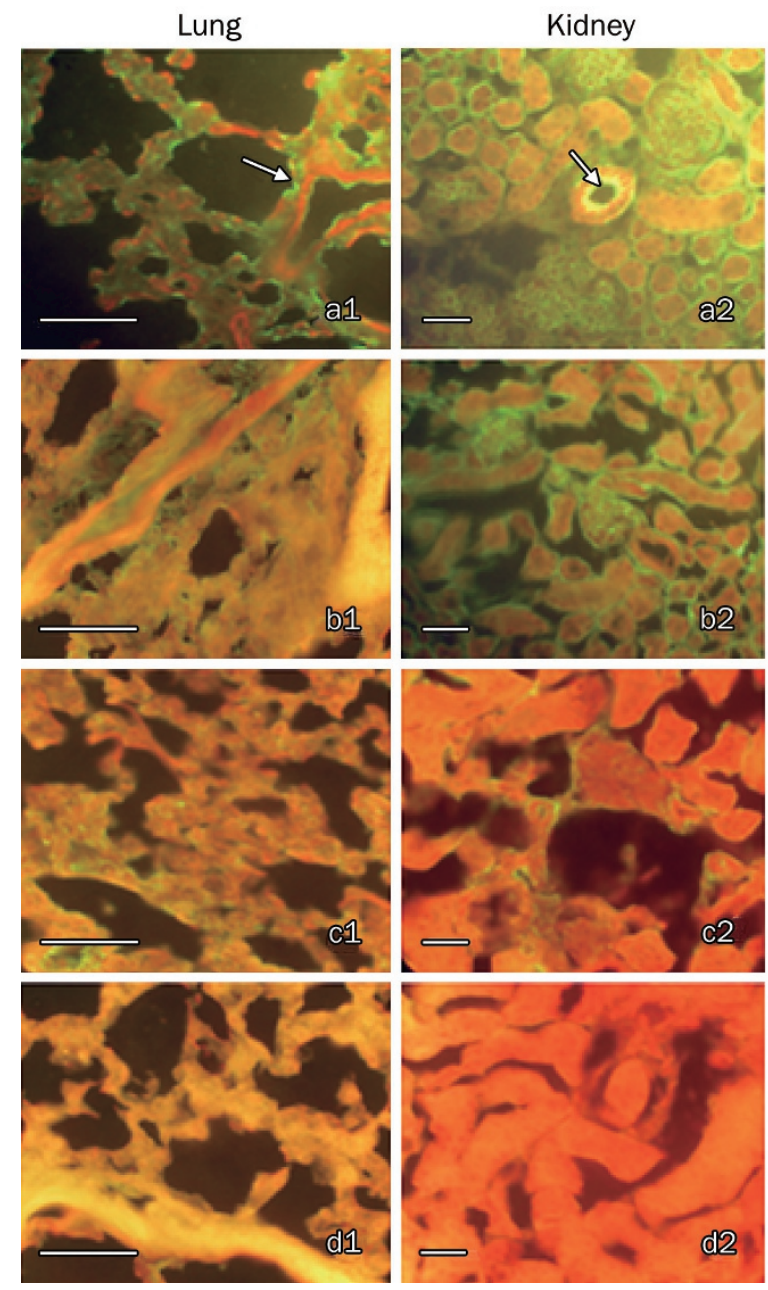
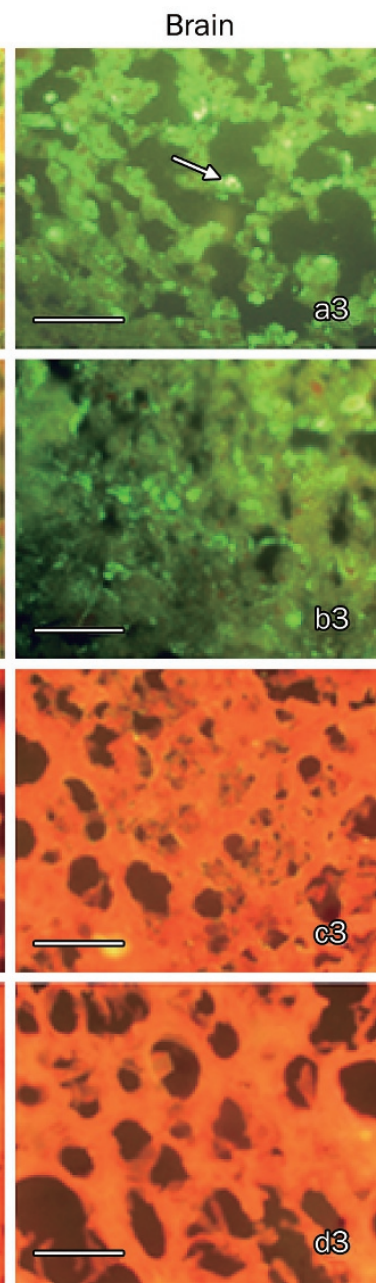

Figure 3. Inhibitory effects of arbidol on viral antigen expressed in organs of suckling mice infected with HTNV (×400). On day 12 and 28 pi, four mice from each group were sacrificed and sections prepared for IFA. (a1-a3) On day 12 pi viral antigen was detected in the organs (arrow) of a placebo-treated animal. (a1) Lung; (a2) Kidney; (a3) Brain; (b1-b3) Viral antigen was detected in the animal treated at 20 $\mathrm{mg} \cdot \mathrm{kg}^{-1} \cdot \mathrm{d}^{-1}$ arbidol on day $12 \mathrm{pi}$. (c1-c3) Viral antigen expressed in a survival animal at $28 \mathrm{dpi}$. (d1-d4) A mock-infected animal. Scale bar $=25 \mu \mathrm{m}$. survivors (day 28 pi).

\section{Effect of arbidol on serum TNF- $\alpha$ levels of HTNV-infected mice}

The concentrations of serum TNF- $\alpha$ were tested by ELISA to determine the immunologic effect of arbidol on mice infected with HTNV. At day 4 pi, the serum TNF-a level in normal animals was $79.56 \mathrm{pg} / \mathrm{mL}$. In comparison, the serum TNF-a concentration in placebo controls was $183.58 \mathrm{pg} / \mathrm{mL}(P<0.05)$.
Compared with placebo controls, treatment with arbidol decreased secretion of TNF- $\alpha$ in a dose-dependent manner $(P<0.05)$. On days 8,12 , and 16 pi, serum TNF-a levels in animals treated with arbidol doses of 10 and $20 \mathrm{mg} \cdot \mathrm{kg}^{-1} \cdot \mathrm{d}^{-1}$ were between $30-80 \mathrm{pg} / \mathrm{mL}$, while those of placebo controls were below the limit of detection $(15.63 \mathrm{pg} / \mathrm{mL})$. The results are shown in Table 2.

Table 2. The effect of arbidol on TNF- $\alpha$ level in serum of HTNV-infected suckling mice. $n=4$. Mean \pm SD. ${ }^{b} P<0.05$ vs Normal controls. ${ }^{e} P<0.05$ vs Placebo controls (determined by One-Way ANOVA).

\begin{tabular}{|c|c|c|c|c|}
\hline \multirow[t]{2}{*}{ Group } & \multicolumn{4}{|c|}{ TNF- $\alpha(p g / m L)$} \\
\hline & $4 \mathrm{dpi}$ & $8 \mathrm{dpi}$ & $12 \mathrm{dpi}$ & $16 \mathrm{dpi}$ \\
\hline $20 \mathrm{mg} \cdot \mathrm{kg}^{-1} \cdot \mathrm{d}^{-1}$ & $46.81 \pm 1.62^{\text {be }}$ & $56.69 \pm 2.63$ & $39.09 \pm 3.25$ & $71.66 \pm 4.12$ \\
\hline $10 \mathrm{mg} \cdot \mathrm{kg}^{-1} \cdot \mathrm{d}^{-1}$ & $63.81 \pm 4.49^{\text {be }}$ & $54.06 \pm 1.25$ & $35.58 \pm 1.97$ & $<15.63$ \\
\hline $5 \mathrm{mg} \cdot \mathrm{kg}^{-1} \cdot \mathrm{d}^{-1}$ & $110.71 \pm 3.58^{\text {be }}$ & $<15.63$ & $48.78 \pm 2.38$ & $<15.63$ \\
\hline Placebo controls & $183.58 \pm 3.90^{\mathrm{b}}$ & $<15.3$ & $<15.63$ & $<15.63$ \\
\hline Normal controls & $79.56 \pm 5.64^{\mathrm{e}}$ & $89.56 \pm 3.78$ & ND & ND \\
\hline
\end{tabular}

Mice were treated by oral gavage for 10 days beginning at $-24 \mathrm{hpi}$. Infected or uninfected mice receiving $0.5 \%$ methylcellulose solution served as placebo controls and normal controls. The detection limit of TNF- $\alpha$ is $15.63 \mathrm{pg} / \mathrm{mL}$. ND: Not determined. 
a
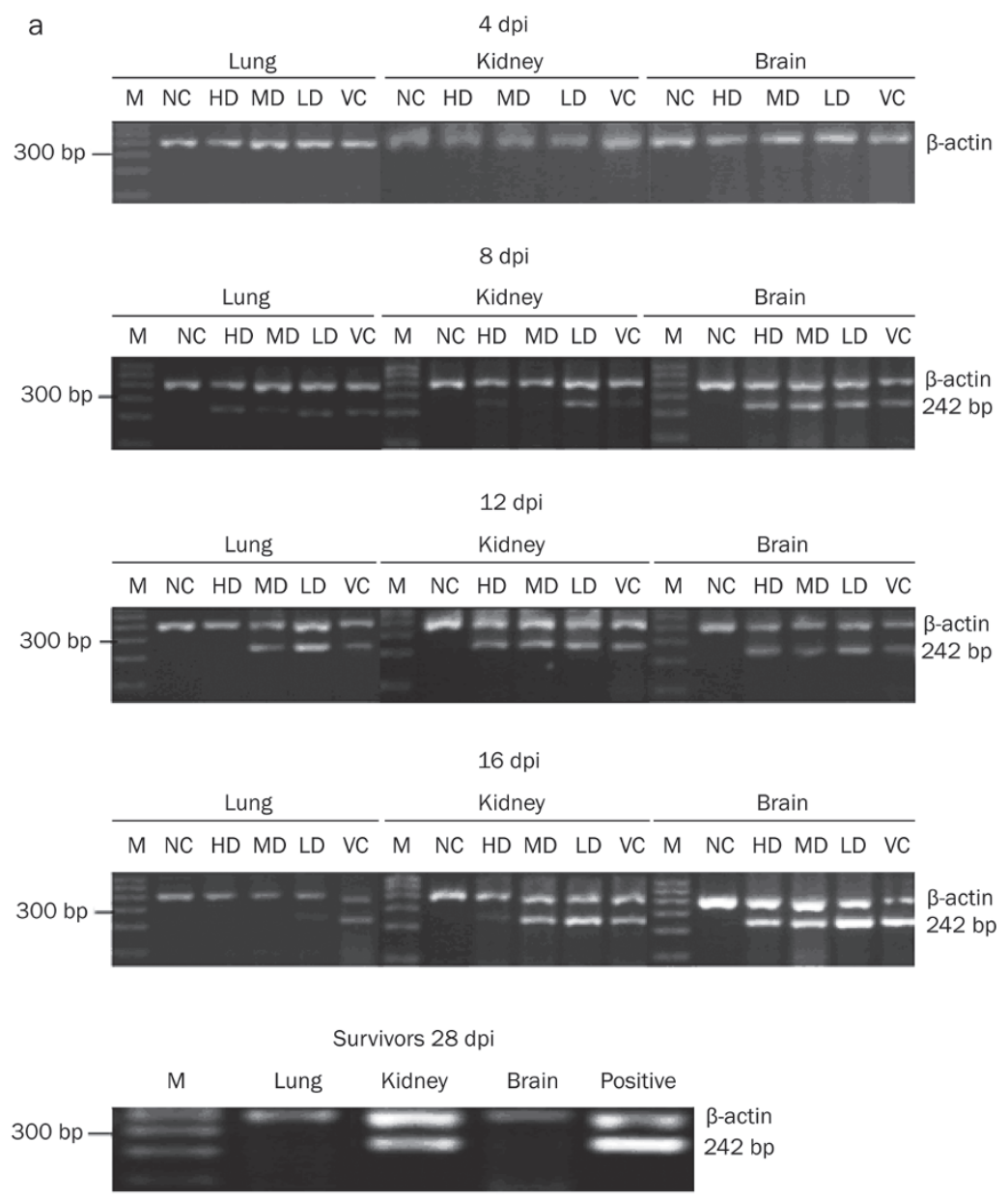

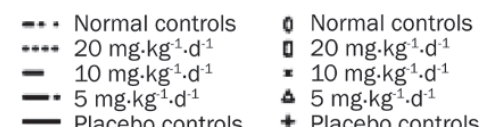

- Placebo controls + Placebo controls

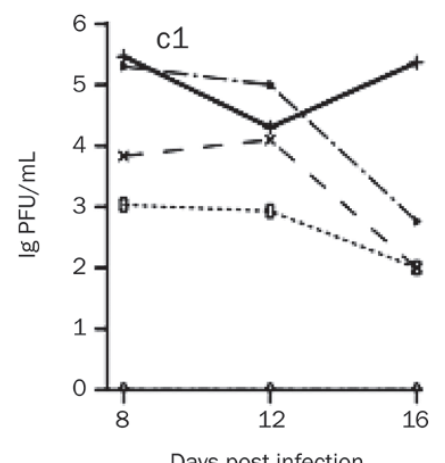

-. $5 \mathrm{mg} \cdot \mathrm{kg}^{-1} \cdot \mathrm{d}^{-1}$

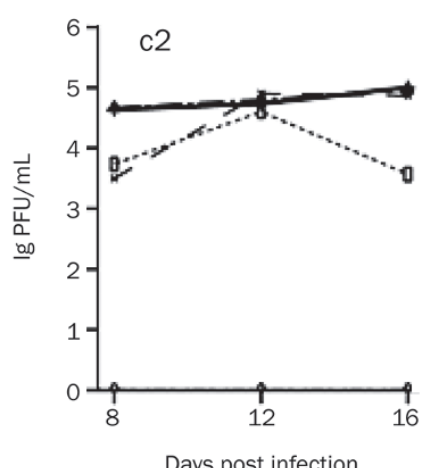

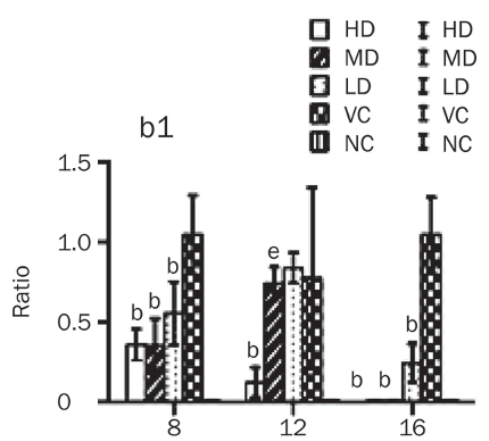
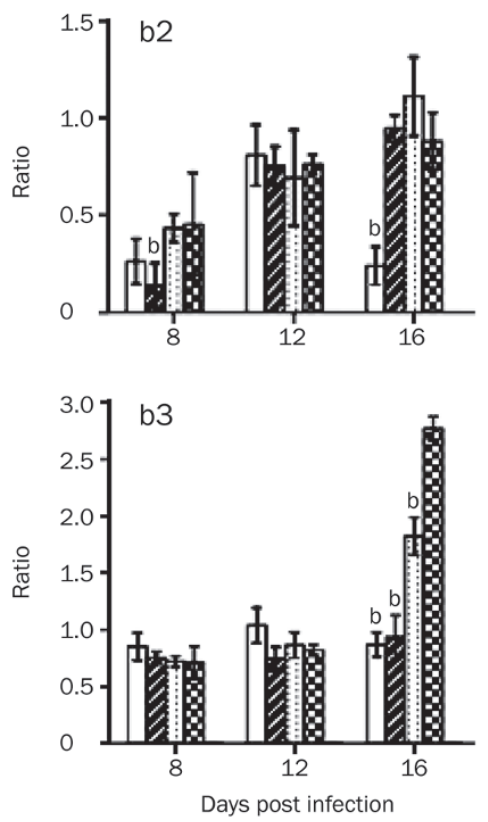

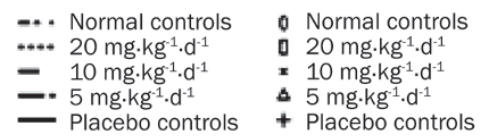

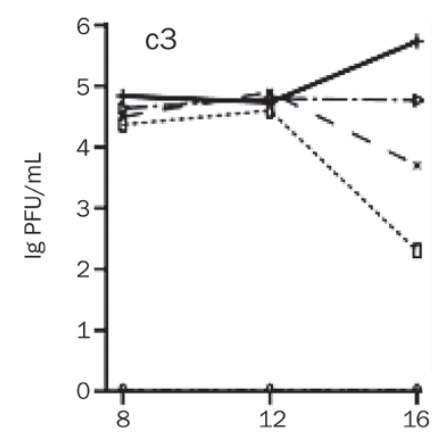

Days post infection

Figure 4. Inhibitory effects of arbidol on viral load in organs of suckling mice infected with HTNV ( $n=4)$. On day 4, 8, 12, and 16 pi, viral loads in the lungs, kidneys and brains were determined by semi-quantitative RT-PCR and plaque assay as described in "Materials and Methods." Each data point represents the mean from three independent experiments. (a) Images of RT-PCR. The S segment of the viral genome (242 bp) was chosen for detection. M: DNA marker; NC: Normal controls; HD: $20 \mathrm{mg} \cdot \mathrm{kg}^{-1} \cdot \mathrm{d}^{-1}$; MD: $10 \mathrm{mg} \cdot \mathrm{kg}^{-1} \cdot \mathrm{d}^{-1}$; $\mathrm{LD}: 5 \mathrm{mg} \cdot \mathrm{kg}^{-1} \cdot \mathrm{d}^{-1}$; vC: Placebo controls; (b) Relative expression of viral S gene mRNA against $\beta$-actin in HTNV infected mice. (b1) Lung; (b2) Kidney; (b3) Brain; ${ }^{\mathrm{b}} P<0.05$ vs placebo-treated controls. ${ }^{\mathrm{e}} \mathrm{P}<0.05$ vs HD. (c) Titers of infectious viral particles in the organs were determined by the standard plaque assay. (c1) Lung; (c2) Kidney; (c3) Brain. 


\section{Discussion}

\section{Antiviral activity of arbidol against HTNV in vitro}

In the present study, arbidol inhibited HTNV replication when added before or after infection, with an $\mathrm{IC}_{50}$ of 0.9 and $1.2 \mu \mathrm{g} / \mathrm{mL}$ and an SI of 17.4 and 13, respectively, indicating that arbidol is highly active against HTNV. It is unknown why no virucidal effect of arbidol was observed in this experiment whereas virucidal effect was exhibited for some other viruses ${ }^{[15]}$. It is possible that the arbidol concentration evaluated is below the $\mathrm{IC}_{50}$. Vero cells are characterized by a chromosomal defect that can block type I interferon (IFN) expression $^{[21]}$. Our data suggest that arbidol can induce durable antiviral activity in Vero cells, not only blocking the adsorption of viral particles onto cells, but also inhibiting the late stage of the viral replication cycle. Therefore, the antiviral activity of arbidol may not be completely due to IFN production, but, rather, related to the effect of arbidol on altering cellular microenvironments to restrain HTNV amplification. Previous reports ${ }^{[16]}$ demonstrated that arbidol's affinity for membranes may inhibit several aspects of the HCV life cycle, and we propose that a similar action mechanism may exist during the inhibition of HTNV infection.

\section{Safety of arbidol for suckling BALB/c mice}

A previous study showed that the $L_{50}$ dose for female $\mathrm{BALB} / \mathrm{c}$ mice with oral gavage treatment was approximately $314 \mathrm{mg} \cdot \mathrm{kg}^{-1} \cdot \mathrm{d}^{-1}[15]$. We demonstrated that the $\mathrm{LD}_{50}$ dose for suckling BALB/c mice orally administered arbidol for 10 days was $78.42 \mathrm{mg} \cdot \mathrm{kg}^{-1} \cdot \mathrm{d}^{-1}$. Furthermore we found that suckling mice infected by HTNV and treated with arbidol at 40 $\mathrm{mg} \cdot \mathrm{kg}^{-1} \cdot \mathrm{d}^{-1}$ showed pronounced toxicity, as evidenced by weight loss, with death occurring 7 or 8 dpi (data not shown). Therefore, the testable doses we chose were 5, 10, and 20 $\mathrm{mg} \cdot \mathrm{kg}^{-1} \cdot \mathrm{d}^{-1}$.

Establishing a newborn BALB/c mouse model for HTNV infection A number of animal models for the study of HFRS exist ${ }^{[22,23]}$, but lethal disease could be induced only in newborn and immunodeficient animals ${ }^{[24-26]}$. Thus, we established a model of infection by ic inoculation of suckling mice with HTNV as used before ${ }^{[20]}$. Infected animals showed characteristic progression of disease findings and lesions caused by the infection, as well as virological parameters detected in the target organs. Moreover, the negative histopathological test results of mock-infected animals (Figure 2) excluded the possibility that the inoculation route could have been directly or indirectly responsible for the lethal disease. All these findings together suggest that suckling BALB/c mice infected with HTNV can be used as a suitable model to evaluate antiviral agents.

\section{Arbidol is effective against HTNV in vivo}

The route of administration of compounds is important in vivo, and arbidol is rather insoluble in aqueous medium. Therefore, oral gavage was used for administration of arbidol in the study. Based on other authors' reports ${ }^{[15]}$ and our results in vitro, treatment of the animals was initiated $24 \mathrm{~h}$ before infection. We demonstrated that orally administered arbidol at 10 or $20 \mathrm{mg} \cdot \mathrm{kg}^{-1} \cdot \mathrm{d}^{-1}$ significantly reduced the appearance of clinical signs of HTNV and increased the survival rate and MTD (Figure 1). By day 28, all survivors were asymptomatic, demonstrated weight gain, and exhibited no histopathological changes in their organs. The expression of viral antigen significantly decreased in the lungs and kidneys, and no HTNV antigen was detected in the brains of survivors. All these findings suggest that arbidol has the ability to elicit protective antiviral activity against HTNV in vivo, with a minimum effective concentration of $10 \mathrm{mg} \cdot \mathrm{kg}^{-1} \cdot \mathrm{d}^{-1}$ as demonstrated in this experiment. Semi-quantitative RT-PCR data showed that the highest viral replication levels in the lungs, kidneys, and brains of placebo controls appeared at day $16 \mathrm{pi}$, which is similar to others' $^{\prime}$ results ${ }^{[25,27]}$, and that animals treated with arbidol showed lower peak levels and/or a delay in reaching peak levels (Figure 4B). Viral titers in the lungs first decreased in a dose- and time-dependent manner, followed by decreases in the brains and then in the kidneys (Figure 4C), as determined by plaque assay, indicating that treatment with arbidol reduces infectious virus as well as total viral RNA in the organs. After treatment with arbidol, no viral mRNA or infectious viral particles were detected in the lungs and brains of survivors. Although viral RNA was demonstrated in the kidneys of all arbidoltreated mice that survived HTNV infection, no infectious viral particles were observed in any of the mice, indicating that the major target tissues of HTNV in suckling mice are the kidneys, but HTNV failed to replicate in the presence of arbidol. Taken together, these results suggest that arbidol can inhibit HTNV replication in vivo, with the difference in efficacy in different organs perhaps being due to the tissue distribution of arbidol and the organization tropism of HTNV. We demonstrated that no viral mRNA or infectious viral particles in tissues of animals infected by HTNV was detected on day 4 pi, suggesting a very low level of virus replication in the organs. This is in agreement with the results of Kim et al ${ }^{[25]}$.

It has been reported that increased plasma levels of TNF-a were found in the blood of HFRS patients during the acute phase $^{[28]}$. The results of Niikura et al ${ }^{[29]}$ confirmed that HTNV infection of endothelial cells might contribute to increased vascular leakage through a prolonged response to TNF-a. In our investigations, serum TNF-a levels were higher on day 4 pi, showing that treatment with arbidol can decrease levels of TNF-a on day 4 pi in a dose-dependent manner (Table 2). Arbidol has been shown to have effects on activating macrophages ${ }^{[14]}$, suggesting that the effect of arbidol on modulating TNF-a level may be due to activating macrophages. Serum levels of TNF-a showed a decrease at days 8, 12, and 16 pi, which may be due to secreted TNF-a binding to TNF-a receptors (TNFR) expressed in the cell membrane or secreted in serum ${ }^{[30-32]}$; thus, resulting in less detection of secreted TNF-a. Higher levels of TNF-a were detected in arbidoltreated animals than placebo controls, suggesting that the mechanism of action of arbidol may not only involve modu- 
lating serum TNF-a levels but also expression of TNFR in the tissues $^{[32-34]}$. Therefore, it is possible that apart from exhibiting anti-HTNV activity, arbidol could have also modulated the TNF responses and protected mice against the lethal challenge.

In conclusion, arbidol has the ability to elicit protective antiviral activity against HTNV in vivo and in vitro. Arbidol was found to present potent inhibitory activity against HTNV when added before or after viral infection in vitro. Orally administered arbidol can reduce histopathological changes, decrease expression of viral antigen and viral load, and modulate the TNF responses. Further experiments are needed to investigate the mechanism of action of arbidol. Arbidol may be a promising candidate for early treatment of Hantavirus infection.

\section{Acknowledgements}

This work was supported by a grant from the National Natural Science Foundation of China (NSFC project № 30873104).

We thank Dr Rhea-Beth MARKOWITZ and Dr Pamela Wall STEEN from the Medical College of Georgia, Augusta, Georgia, USA for critical reading of the manuscript.

\section{Author contribution}

Hai-ying DENG performed research, analyzed data, and wrote the paper; Fan LUO performed research and analyzed data; Li-qiao SHI analyzed data; Qiong ZHONG and Ying-juan LIU performed research; Zhan-qiu YANG designed the study, analyzed data, and wrote the manuscript.

\section{References}

1 Kruger DH, Urich R, Lundkvist A. Hantavirus infections and their prevention. Microbes Infect 2001; 3: 1129-44.

2 Muranyi W, Bahr U, Zeier M, van der Woude FJ. Hantavirus infection. J Am Soc Nephrol 2005; 16: 3669-79.

3 Lee HW. Epidemiology and pathogenesis of hemorrhagic fever with renal syndrome. In: Elliott RM, editor. The Bunyaviridae. New York (NY): Plenum Press; 1996. p253-67.

4 Schmaljohn C, Hjelle B. Hantaviruses-A global disease problem. Emerg Infect Dis 1997; 3: 95-104.

5 Borio L, Inglesby T, Peters CJ, Schmaljohn AL, Hughes JM, Jahrling PB, et al. Hemorrhagic fever viruses as biological weapons: medical and public health management. JAMA 2002; 287: 2391-405.

6 Kanerva M, Mustonen J, Vaheri A. Pathogenesis of Puumala and other Hantavirus infections. Rev Med Virol 1998; 8: 95-104.

7 Klempa B, Stanko M, Labuda M, Ulrich R, Meisel H, Kruger DH. Central European Dobrava Hantavirus isolate from a striped field mouse (Apodemus agrarius). J Clin Microbiol 2005; 43: 2756-63.

8 Hooper J, Li D. Vaccines against Hantaviruses. Curr Top Microbiol Immunol 2001; 256: 171-91.

9 Robert W Sidwell, Smee DF. Viruses of the Bunya- and Togaviridae families: potential as bioterrorism agents and means of control. Antiviral Res 2003; 57: 101-11.

10 Huggins JW, Hsiang CM, Cosgriff TM, Guang MY, Smith JI, Wu ZO, et al. Prospective, double-blind, concurrent, placebo-controlled clinical trial of intravenous ribavirin therapy of hemorrhagic fever with renal syndrome. J Infect Dis 1991; 164: 1119-27.

11 Chapman LE, Mertz GJ, Peters CJ. Intravenous ribavirin for hantavirus pulmonary syndrome: safety and tolerance during 1 year of open-label experience. Ribavirin Study Group. Antiviral Ther 1999; 4: 211-9.

12 Salmon-Céron D, Chauvelot-Moachon L, Abad S, Silbermann B, Sogni P. Mitochondrial toxic effects and ribavirin. Lancet 2001; 357: 1803-4.

13 Ohnson EM. Developmental toxicity and safety evaluations of ribavirin. Pediatr J Infect Dis 1990; 9: S85-7.

14 Glushkov RG, Gus'kova TA, Krylova LI, Nikolaeva IS. Mechanisms of arbidole's immunomodulating action. Vestn Ross Akad Med Nauk 1999; 3: 36-40. In Russian.

15 Shi LQ, Xiong HR, He J, Deng HY, Li Q, Zhong Q, et al. Antiviral activity of arbidol against influenza $A$ virus, respiratory syncytial virus, rhinovirus, coxsackie virus and adenovirus in vitro and in vivo. Arch Virol 2007; 152: 1447-55.

16 Boriskin YS, Pecheur El, Polyak SJ. Arbidol: a broad-spectrum antiviral that inhibits acute and chronic HCV infection. Virol J 2006; 3: 56.

17 Brooks MJ, Sasadeusz JJ, Tannock GA. Antiviral chemotherapeutic agents against respiratory viruses: where are we now and what's in pipeline? Curr Opin Pulm Med 2004; 10: 197-203.

18 Denizot F, Lang R. Rapid colorimetric assay for cell growth and survival. Modifications to the tetrazolium dye procedure giving improved sensitivity and reliability. J Immunol Methods 1986; 89: 271-7.

19 Severson WE, Schmaljohn CS, Javadian A, Jonsson CB. Ribavirin causes error catastrophe during Hantaan virus replication. J Virol 2003; 77: 481-8.

20 Liu YJ, Yang ZQ, Deng HY, Xiao H, Qu CF. Separation and anti-hantaan virus activity of extracts from alternanthera philoxcroides in vitro and in vivo. J Wuhan Univ (Nat Sci) 2007; 12: 1143-7.

21 Diaz MO, Ziemin S, Lebeau MM, Pitha P, Smith SD, Chilcote RR, et al. Homozygous deletion of the alpha-interferon and beta-1-interferon genes in human leukemia and derived cell lines. Proc Natl Acad Sci USA 1988; 85: 5259-63.

22 Lee PW, Amyx HL, Gibbs CJ Jr, Gajdusek DC, Lee HW. Propagation of Korean hemorrhagic fever virus in laboratory rats. Infect Immun 1981; 31: 334-8.

23 Yoshimatsu K, Arikawa J, Ohbora S, Itakura C. Hantavirus infection in SCID mice. J Vet Med Sci 1997; 59: 863-8.

24 Brian BG, Michael RH. Animal models of highly pathogenic RNA viral infections: Hemorrhagic fever viruses. Antiviral Res 2008; 78: 79-90.

25 Gum RK, Kelly T, Mckee JR. Pathogenesis of Hantaan virus infection in suckling mice: clinical, virologic, and serologic observations. Am J Trop Med Hyg 1985; 34: 388-95.

26 Yamanouchi T, Domae K, Tanishita O, Takahashi Y, Yamanishi K, Takahashi $\mathrm{M}$, et al. Experimental infection in newborn mice and rats by hemorrhagic fever with renal syndrome (HFRS) virus. Microbiol Immunol 1984; 28: 1345-53.

27 Huggins JW, Kim GR, Brand OM, McKee KT Jr. Ribavirin therapy for Hantaan virus infection in suckling mice. J Infect Dis 1986; 153: 489-97.

28 Linderholm M, Ahlm C, Settergren B, Waage A, Tarnvik A. Elevated plasma levels of tumor necrosis factor (TNF)-alpha soluble TNF receptors interleukin (IL)- 6 and IL-10 in patients with hemorrhagic fever with renal syndrome. J Infect Dis 1996; 173: 38-43.

29 Niikura M, Maeda A, Ikegami T, Saijo M, Kurane I, Morikawa S. Modification of endothelial cell functions by Hantaan virus infection: prolonged hyper-permeability induced by TNF-alpha of Hantaan virusinfected endothelial cell monolayers. Arch Virol 2004; 149: 1279-92.

30 Wei XW, Gong JF, Zhu J, Wang PF, Li N, Zhu WM, et al. The suppressive effect of triptolide on chronic colitis and TNF- $\alpha$ /TNFR2 signal pathway in interleukin-10 deficient mice. Clin Immunol 2008; 129: 211-8.

31 Strandin T, Hepojoki J, Wang H, Vaheri A, Lankinen H. Hantaviruses 
and TNF-alpha act synergistically to induce ERK1/2 inactivation in Vero E6 cells. Virol J 2008; 5: 110.

32 Wajant H, Pfizenmaier K, Scheurich P. Tumor necrosis factor signaling. Cell Death Differ 2003; 10: 45-65.

33 Krogerus L, Soots A, Loginov R, Bruggeman C, Lautenschlager I. CMV increases tubular apoptosis through the TNF- $\alpha-T N F-R 1$ pathway in a rat model of chronic renal allograft rejection. Transplant Immunol 2008; 18: 232-6.

34 Temonen M, Lankinen H, Vapalahti L, Ronni T, Julkunen I, Vaheri A. Effect of interferon- $\alpha$ and cell differentiation on Puumala virus infection in human monocyte/macrophages. Virology 1995; 206: 8-15.

\section{Correction}

Topotecan inhibits cancer cell migration by down-regulation of chemokine CC motif receptor 7 and matrix metalloproteinases. Acta Pharmacol Sin 2009; 30 (5): 628-636.

Prof Sheng-tao YUAN and Prof Lu-yong ZHANG were the co-corresponding authors for this paper. 